\title{
Public Sector Innovation Support by European States: Its Characteristics and Impact on Firms
}

\author{
Marta Orviska - Juraj Nemec
}

\begin{abstract}
:
In this paper we are concerned with the impact the public sector has on private sector innovation. Perhaps the most important issue is whether public sector innovation, or lack of it, impacts upon private sector firms. But we are also concern the extent perceptions of innovation across jurisdictions and also the characteristics of firms, which benefit from public sector innovation. There is a particular focus on the role of the Internet. In doing this we make use of Eurobarometer data on firms and their attitudes to public sector innovation. We have established that firms benefit from public sector innovation. The factors, which impact on growth, include improvements due to Internet form filling and the reduction in the government's response time with respect to government services. The factors that impact on firm innovation, which may be tomorrow's growth, include the access to information on government services and also factors, which reduce costs.
\end{abstract}

Key words: Innovations; Public sector; Private sector.

JEL classification: $\mathrm{O} 31$

\section{Introduction}

According to Kattel et al. (2013) scholarly efforts to delineate and conceptualize public sector innovation can be attributed to three main periods:

1) Schumpeterian period: innovations and public sector are related to a larger theory of how evolutionary change takes place in societies, mainly associated with Schumpeter (1912\&1939);

2) organizational theory period: innovations in the public sector are similar to innovations in private companies, mostly associated with early organizational theory and with Wilson (1989);

3) autochthonous theory period is the most recent trend to disassociate public and private sector innovations. This current literature dealing with public sector innovation tries to move away both from private sector Schumpeterian approaches and from organizational level changes towards innovation genuinely attributable to public sector and towards discussing innovations

Prof. Ing. Marta Orviska, PhD. - professor; Faculty of Economics, Matej Bel University, Tajovskeho 10, 97401 Banska Bystrica, <marta.orviska@umb.sk>.

Prof. Ing. Juraj Nemec, CSc. - professor; Faculty of Economics, Matej Bel University, Tajovskeho 10, 97401 Banska Bystrica and Faculty of Economics and Administration, Lipova 41a, 60200 Brno, <juraj.nemec@umb.sk>.

This research was supported by the $7 F P$ research project LIPSE ("Learning from Innovation in Public Sector Environments"). 

and Impact on Firm.

in public services and governance (Hartley 2005; Moore and Hartley 2008; also Verhoest et al 2006; Pollitt 2011).

However, we feel that the need for linking together public sector and private sector innovations is still current and deserves more attention. There has been some work done on innovation in the public sector and its impact on the private sector (e.g. Albury, 2005; North, Smallbone and Vickers, 2001; Windrum and Koch, 2008). However, it has been argued that in reality there is a dearth of research and much we do not know (Bloch and Bugge, 2013), in particular with respect to the role of the user of public sector innovation. The problems of public sector change and innovation are particularly important in a period of financial turmoil which has followed the 2008 crisis and has seen governments attempting to cut back on spending and to a large degree the services they offer (Bason, 2010). This change in itself is often a spur to innovation, but coincidentally perhaps it comes at a time when developments in IT are providing a potential revolution in many aspects of government services (Heeks, 1999).

In this paper we build on the above in analysing the impact of public sector innovation on private sector firms. More generally we are also concerned with the impact the public sector has on private sector innovation. Perhaps the most important issue is whether public sector innovation, or lack of it, impacts upon private sector firms. But we will also concern the extent perceptions of innovation across jurisdictions and also the characteristics of firms, which benefit from public sector innovation. There is a particular focus on the role of the Internet. In doing this we make use of Eurobarometer data on firms and their attitudes to public sector innovation. The paper proceeds as follows; in the next section the data are presented. In the penultimate section we present the results of our analysis and finally we conclude the paper.

\section{Data and methodology}

The survey was carried out between the 16th of February and the 7th of March 2012. It was a part of the Flash Eurobarometer series, Flash Eurobarometer 343 to be specific, and was carried out for the EUROPEAN COMMISSION, Directorate-General for Enterprise and Industry. It covers businesses employing 1 or more persons in the manufacturing, retail, services and industry sectors within the European Union. The survey covered all the countries of the EU and in addition, several other European countries. Whenever a company was eligible, the selected respondent had to be a general manager, a financial director or a significant owner. All interviews were hold by using the TNS e-Call centre. The sample was selected from an international business database, with some additional sample from local sources in countries where necessary. Quotas were applied on both company size (using three different ranges: 1-9 employees, 10-49 employees, 50 employees or more) and sectors (retail, services, manufacturing and industry). 
European Financial and Accounting Journal, 2015, vol. 10, no. 1, pp. 19-31.

The variables we will be analysing are summarised in each Table containing the regression results and the independent variables are defined in an appendix. The average response and the standard deviation of that response to a question: whether they perceived public services as having improved in the previous three years` is shown in the first two columns of Table 1 . The potential responses were (i) no, deteriorated, (ii) stayed the same and (iii) yes improved. These were coded 1 to 3 respectively. Hence we can see that in Belgium and Denmark the average response laid above 2 indicated a balance of those who saw improvement. Those in Greece, however, perceived deterioration on average as did other those in countries with deep financial problems such as Italy and Spain. In general most countries saw some improvement, but not so for many of the countries of Central and Eastern Europe including Slovakia and the Czech Republic. The final two columns relate to a question on whether the respondent thought that overall the public services were doing a good job in creating the right conditions for their company to innovate. Responses ranged from strongly disagree to strongly agree, coded 1 to 4 respectively. Hence a value of 2.5 roughly approximated to a neutral response. The responses overall were hardly enthusiastic, although firms in several countries, particularly those on the Baltic were more so than others. But again countries with severe public sector financial problems and also several Central and East European countries, including Slovakia and the Czech Republic had particularly unfavourable views.

\section{Tab 1: The Distribution of Attitudes to the Impact of the Public Sector on Private Sector Innovation}

\begin{tabular}{lcccc}
\hline & \multicolumn{2}{c}{ PS improved overall (1-3) } & Overall support for innovation (1-4) \\
& Mean & Std dev & Mean & Std dev \\
\hline Belgium & 2.182927 & 0.660143 & 2.472868 & 0.799587 \\
Denmark & 2.157676 & 0.664606 & 2.381132 & 0.765016 \\
Greece & 1.749153 & 0.763623 & 1.804124 & 0.834256 \\
Spain & 1.977064 & 0.687776 & 2.258547 & 0.852903 \\
France & 2.151188 & 0.666802 & 2.489496 & 0.793324 \\
Germany & 2.048128 & 0.644909 & 2.569794 & 0.802978 \\
Ireland & 1.996241 & 0.664451 & 2.13879 & 0.925024 \\
Italy & 1.844548 & 0.63719 & 2.216561 & 0.845402 \\
Luxembourg & 2.204545 & 0.697435 & 2.818182 & 0.787189 \\
Netherlands & 2.145679 & 0.568141 & 2.504673 & 0.738678 \\
Austria & 2.050193 & 0.571776 & 2.587189 & 0.756198 \\
Portugal & 2.250896 & 0.787577 & 2.475177 & 0.901415 \\
Finland & 2.064151 & 0.529112 & 2.632867 & 0.66081 \\
Sweden & 2.261803 & 0.545475 & 2.655022 & 0.782895 \\
UK & 1.967442 & 0.643316 & 2.400891 & 0.80434 \\
\hline
\end{tabular}


Orviska, M. - Nemec, J.: Public Sector Innovation Support by European States: Its Characteristics and Impact on Firm.

\begin{tabular}{|c|c|c|c|c|}
\hline & \multicolumn{2}{|c|}{ PS improved overall (1-3) } & \multicolumn{2}{|c|}{ Overall support for innovation (1-4) } \\
\hline & Mean & Std dev & Mean & Std dev \\
\hline Cyprus & 2.105882 & 0.707503 & 2.318681 & 1.094218 \\
\hline Czech Republic & 1.945525 & 0.647222 & 2.206406 & 0.712211 \\
\hline Estonia & 2.303226 & 0.585254 & 2.885135 & 0.760627 \\
\hline Hungary & 2.025105 & 0.727172 & 2.518248 & 0.794691 \\
\hline Latvia & 2.231707 & 0.660893 & 2.760638 & 0.795135 \\
\hline Lithuania & 2.25731 & 0.680304 & 2.616667 & 0.886113 \\
\hline Malta & 2.382979 & 0.734794 & 2.62766 & 0.903804 \\
\hline Poland & 2.002273 & 0.638545 & 2.322176 & 0.769417 \\
\hline Slovakia & 1.822785 & 0.684443 & 2.090253 & 0.848579 \\
\hline Slovenia & 1.958333 & 0.641426 & 2.202128 & 0.896574 \\
\hline Bulgaria & 2.137809 & 0.71366 & 2.095941 & 0.868173 \\
\hline Romania & 2.118943 & 0.739275 & 2.547126 & 1.011209 \\
\hline Norway & 2.069364 & 0.661076 & 2.606897 & 0.75734 \\
\hline Turkey & 2.436842 & 0.721849 & 2.907928 & 0.892541 \\
\hline Macedonia & 2.134078 & 0.803021 & 2.77907 & 0.77083 \\
\hline Croatia & 2.108696 & 0.668683 & 1.964103 & 0.851768 \\
\hline Switzerland & 2.159341 & 0.567923 & 2.627551 & 0.722571 \\
\hline
\end{tabular}

Source: Authors`calculations from Eurobarometer.

Note: Higher values denote more improvement or more support, PS denotes public sector.

\section{Regression results and their discussion}

In the first set of regressions (Table 2) we examine the responses to a question, which asked: based on the experience of your company, which level of government is the most innovative. The potential responses were (i) municipal/local, (ii) regional/ sub-national, (iii) national and (iv) EU. Because only one response was possible that mutually excluded others, the regression technique of multinomial logit was used. This estimates equations for three out of the four possible responses, with the fourth being derived by default. The results would appear to reflect the various firms' degree of contact with the various authorities, rather than their degree of innovativeness, which suggests that people should be careful in interpreting the raw data. For example, firms with a high proportion of their sales for the domestic market tend to favour local municipal government as being most innovative and, by default, the EU as least innovative. Of course the reverse also applies for firms with large export markets. Large firms tend to favour national governments as being the most innovative compared to the alternatives. There are also significant differences, as one might expect, among countries with particularly financially troubled economies tending to see the EU as the most innovative, but the Baltic countries, e.g., seeing national governments as the most 
European Financial and Accounting Journal, 2015, vol. 10, no. 1, pp. 19-31.

innovative. Firms in almost no country tended to see local or regional government as the most innovative.

Tab 2: Estimations on Importance of Jurisdiction

\begin{tabular}{|c|c|c|c|c|c|c|}
\hline \multirow{2}{*}{ Variable } & \multicolumn{2}{|c|}{ Local } & \multicolumn{2}{|c|}{ Regional } & \multicolumn{2}{|c|}{ European Union } \\
\hline & coefficient & t statistic & coefficient & t statistic & coefficient & t statistic \\
\hline \multicolumn{7}{|l|}{ Firm variables } \\
\hline Year started & 0.0297 & $(0.38)$ & 0.0863 & $(0.97)$ & 0.1438 & $(1.55)$ \\
\hline Size & $-0.2260 * *$ & $(6.43)$ & $-0.1443 * *$ & $(3.66)$ & $-0.1484 * *$ & $(3.55)$ \\
\hline $\begin{array}{l}\text { Domestic } \\
\text { sales }\end{array}$ & $0.0045 * *$ & $(3.45)$ & -0.0010 & $(0.75)$ & $-0.0076 * *$ & $(5.68)$ \\
\hline Manufacturing & -0.0227 & $(0.24)$ & 0.0585 & $(0.55)$ & 0.1261 & $(1.12)$ \\
\hline Retail & -0.1297 & $(1.52)$ & -0.0493 & $(0.51)$ & 0.0436 & $(0.42)$ \\
\hline Services & -0.1386 & $(1.52)$ & $-0.2620^{*}$ & $(2.45)$ & -0.0571 & $(0.49)$ \\
\hline \multicolumn{7}{|c|}{ Country dummies } \\
\hline Belgium & $-1.7893 * *$ & $(7.59)$ & $-0.9641 * *$ & $(4.27)$ & -0.3362 & $(1.01)$ \\
\hline Denmark & $-1.3551 * *$ & $(6.50)$ & $-2.3577 * *$ & $(7.82)$ & $-0.7904 *$ & $(2.28)$ \\
\hline Greece & $-1.3085^{* *}$ & $(4.37)$ & $-0.7003 *$ & $(2.36)$ & $2.4305^{* *}$ & $(7.99)$ \\
\hline Spain & $-1.9886 * *$ & (9.14) & $-0.7726 * *$ & (3.87) & $0.7055^{* *}$ & $(2.60)$ \\
\hline France & $-1.5382 * *$ & $(8.12)$ & $-0.9313 * *$ & $(4.78)$ & $-0.7197 *$ & $(2.27)$ \\
\hline Ireland & $-1.7875^{* *}$ & $(8.36)$ & $-2.7332 * *$ & $(8.33)$ & -0.0474 & $(0.16)$ \\
\hline Italy & $-0.6171 * *$ & (3.07) & $-0.5921 * *$ & $(2.70)$ & $0.6513^{*}$ & $(2.22)$ \\
\hline Luxembourg & $-2.6453 * *$ & $(6.42)$ & $-1.9958 * *$ & $(5.20)$ & $-1.0040 *$ & $(2.02)$ \\
\hline Netherlands & $-1.2913 * *$ & (7.01) & $-1.3628 * *$ & $(6.57)$ & -0.4797 & (1.60) \\
\hline Austria & $-0.7269 * *$ & (3.18) & 0.0082 & $(0.04)$ & -0.7517 & $(1.75)$ \\
\hline Portugal & $-1.7321 * *$ & (7.72) & $-1.7976^{* *}$ & (6.89) & 0.3129 & (1.07) \\
\hline Finland & $-1.1595^{* *}$ & $(5.70)$ & $-0.9397 * *$ & (4.29) & $-0.7906^{*}$ & (2.18) \\
\hline Sweden & $-1.3471 * *$ & (6.34) & $-1.5895^{* *}$ & $(6.27)$ & $-1.2643^{* *}$ & $(3.01)$ \\
\hline UK & $-0.8496^{* *}$ & $(4.55)$ & $-1.1958 * *$ & $(5.47)$ & -0.6048 & (1.82) \\
\hline Cyprus & $-1.4446 * *$ & (3.02) & $-0.9747 *$ & (2.03) & $2.0200 * *$ & $(4.88)$ \\
\hline $\begin{array}{l}\text { Czech } \\
\text { Republic }\end{array}$ & $-0.5588 *$ & $(2.32)$ & -0.1793 & $(0.72)$ & $0.9872 * *$ & $(3.08)$ \\
\hline Estonia & $-1.9160 * *$ & $(6.87)$ & $-2.4420 * *$ & $(6.30)$ & 0.0377 & $(0.11)$ \\
\hline Hungary & $-0.5046^{*}$ & (2.14) & $-0.8630 * *$ & (3.13) & $1.0741 * *$ & $(3.41)$ \\
\hline Latvia & -0.3694 & (1.41) & $-0.9012 * *$ & $(2.85)$ & $1.1187 * *$ & (3.29) \\
\hline Lithuania & $-1.0782 * *$ & (3.81) & $-2.2736 * *$ & $(4.86)$ & $1.3307 * *$ & (4.08) \\
\hline Malta & $-1.2280 * *$ & $(3.56)$ & $-2.2558 * *$ & $(4.01)$ & $1.2505 * *$ & (3.39) \\
\hline Poland & 0.4019 & (1.81) & 0.0224 & (0.09) & $1.9071 * *$ & (6.38) \\
\hline Slovakia & $-0.9027 * *$ & (3.97) & $-0.8698 * *$ & (3.48) & 0.4961 & (1.56) \\
\hline Slovenia & $-0.9486 * *$ & (3.54) & $-1.6344 * *$ & (4.61) & 0.3725 & (1.04) \\
\hline Bulgaria & $-1.4087 * *$ & $(6.25)$ & $-2.1196^{* *}$ & (6.79) & $0.8946^{* *}$ & (3.11) \\
\hline Romania & $-0.9893 * *$ & $(5.15)$ & $-1.8858 * *$ & (7.35) & $0.8502 * *$ & $(3.10)$ \\
\hline Norway & $-1.8504 * *$ & (7.44) & $-2.2312 * *$ & (6.83) & -0.6535 & (1.72) \\
\hline Turkey & $-0.9830 * *$ & $(5.01)$ & $-1.0017 * *$ & (4.63) & $0.8570 * *$ & (3.12) \\
\hline Macedonia & $-1.3429 * *$ & (5.38) & $-1.4797 * *$ & (5.04) & 0.1301 & $(0.38)$ \\
\hline Croatia & $-1.6400 * *$ & (5.68) & $-1.0470 * *$ & (3.67) & $1.0784 * *$ & (3.43) \\
\hline Switzerland & $-0.8164 * *$ & (3.43) & -0.4105 & (1.66) & $-1.4154 *$ & $(2.48)$ \\
\hline Constant & $1.0927 * *$ & $(4.55)$ & $0.8656 * *$ & $(3.29)$ & -0.3463 & $(1.08)$ \\
\hline \multicolumn{2}{|c|}{ Observations 7142} & Lo & kelihood 8 & & ikelihood ra & 101520 \\
\hline
\end{tabular}

Source: Authors`calculations from Eurobarometer. 

and Impact on Firm.

Notes: Estimated by multinomial logit. The dependent variable relates to the perceived level of government, which is the most innovative. The responses relate to (i) municipal/local, (ii) regional/sub-national, (iii) national and (iv) European Union. **/* denotes significance at the $1 \% / 5 \%$ levels of significance.

In Tables 3 and $3 a$ we examine the impact of the public sector on private sector growth and innovation. The first two columns relate to growth. In the first we find that firms, which have perceived public sector services as having improved, have experienced greater growth. This is significant at the $1 \%$ level of significance. We assume that such perceptions are based on reality and hence conclude that improvements in public sector innovation stimulate private sector growth. In terms of the control variables, we note that young firms grow more rapidly than older ones. This was not unexpected. More surprising perhaps is that large firms grow more rapidly also. This is likely to be a subject to reverse causality, with firms who have grown more rapidly tending to be larger. Finally firms in the manufacturing sector grew rapidly in this time period. The second half of the table also shows significant differences among countries. In the next equation we analyse which aspects of public sector improvement have had most effect on private sector growth. There were five possibilities relating to the introduction of (i) the possibility of filling in government forms over the Internet, (ii) the reduction in time and effort needed to fill in forms, (iii) access to information on government services over the Internet, (iv) a reduction in the time required for permits or licenses, (v) a faster response time for government services and (vi) a reduction in financial costs to the country. The significant factors from the above were (i) and (v). The final two columns relate to whether the firm had introduced any innovations since January 2009. Once again firms, which have perceived public sector services as having improved, were more likely to have innovated. But this time as shown in the final column, the factors, which were particularly important in facilitating this, were (iii) access to information on government services over the Internet and (vi) a reduction in financial costs to the company. With respect to the control variables, larger firms are more likely to innovate, as they tend to focus on export markets, rather than the domestic market. Of the different sectors, the manufacturing one was most likely to see innovation. There are substantial differences among countries, with Greece again faring poorly but not Spain. This time firms in Slovakia and the Czech Republic also did well. 
European Financial and Accounting Journal, 2015, vol. 10, no. 1, pp. 19-31.

\section{Tab 3: Impact of Public Services on Firms' Growth and Innovation}

\begin{tabular}{|c|c|c|c|c|}
\hline & Growth & Growth & Innovation & Innovation \\
\hline \multicolumn{5}{|l|}{ Public Sector Services } \\
\hline \multirow{2}{*}{ Improved overall } & $0.1659 * *$ & & $0.1186^{* *}$ & \\
\hline & $(9.08)$ & & (5.29) & \\
\hline \multirow{2}{*}{$\begin{array}{l}\text { Internet government } \\
\text { form filling }\end{array}$} & & $0.0443 *$ & & \\
\hline & & $(2.39)$ & & \\
\hline \multirow{2}{*}{$\begin{array}{l}\text { Response time for } \\
\text { government services }\end{array}$} & & $0.0795 * *$ & & \\
\hline & & $(3.52)$ & & \\
\hline \multirow{2}{*}{$\begin{array}{l}\text { Access to information } \\
\text { on government services }\end{array}$} & & & & $0.0483^{*}$ \\
\hline & & & & $(2.34)$ \\
\hline Reduction in financial & & & & $0.1373 * *$ \\
\hline Costs & & & & $(4.16)$ \\
\hline \multicolumn{5}{|l|}{ Firm characteristics } \\
\hline \multirow{2}{*}{ Year started } & $0.3638 * *$ & $0.354 * *$ & 0.0048 & 0.0759 \\
\hline & (11.13) & $(9.04)$ & $(0.13)$ & $(1.88)$ \\
\hline \multirow{2}{*}{ Size } & $0.2009 * *$ & $0.202 * *$ & $0.3226^{* *}$ & $0.3187 * *$ \\
\hline & $(14.58)$ & $(14.13)$ & $(18.81)$ & $(18.41)$ \\
\hline \multirow{2}{*}{ Log Domestic sales } & $-0.1421 * *$ & $-0.1575^{* *}$ & $-0.1219 * *$ & $-0.113 * *$ \\
\hline & $(7.55)$ & $(6.79)$ & $(5.11)$ & $(4.65)$ \\
\hline \multirow{2}{*}{ Manufacturing } & $0.1073 * *$ & $0.138 * *$ & $0.3962 * *$ & $0.3387 * *$ \\
\hline & $(2.98)$ & $(3.42)$ & $(8.88)$ & $(7.52)$ \\
\hline \multirow{2}{*}{ Retail } & 0.0449 & $0.0851 *$ & $0.2935 * *$ & $0.2508 * *$ \\
\hline & $(1.36)$ & $(2.40)$ & $(7.19)$ & $(6.05)$ \\
\hline \multirow{2}{*}{ Services } & 0.0443 & 0.0667 & $0.253 * *$ & $0.2389 * *$ \\
\hline & $(1.22)$ & $(1.74)$ & $(5.63)$ & $(5.24)$ \\
\hline
\end{tabular}

Source: Authors`calculations from Eurobarometer.

Notes: The first two columns estimated by ordered probit. Dependent variable takes a value of 1 if the companies turnover in 2001 decreased by over $25 \%, 2$ if it fell by between $5 \%-25 \%, 3$ if it remained approximately the same, 4 if it grew by $5 \%-25 \%$ and 5 if it grew by more than $25 \%$. The third and fourth columns were estimated by binomial probit. The dependent variable related to whether the company had introduced any innovations since January 2009 , and if so was coded 1 . **/* denotes significance at the $1 \% / 5 \%$ levels of significance. 
Orviska, M. - Nemec, J.: Public Sector Innovation Support by European States: Its Characteristics and Impact on Firm.

Tab 3A Impact of Public Services on Firms' Growth and Innovation

\begin{tabular}{|c|c|c|c|c|}
\hline & Growth & Growth & Innovation & Innovation \\
\hline \multicolumn{5}{|c|}{ Country Dummy Variables } \\
\hline Belgium & -0.12 & & -0.1283 & $-0.2305^{*}$ \\
\hline Denmark & -0.043 & & -0.1019 & 0.1347 \\
\hline Greece & $-1.084^{* *}$ & $-1.161^{* *}$ & $-0.6717^{* *}$ & $-0.6774^{* *}$ \\
\hline Spain & $-1.039^{* *}$ & $-1.042^{* *}$ & 0.071 & 0.1199 \\
\hline France & $-0.288^{* *}$ & $-0.3009^{* *}$ & $-0.4721^{* *}$ & $-0.3784^{* *}$ \\
\hline Ireland & $-0.8688^{* * *}$ & $-0.9417^{* *}$ & 0.1525 & 0.1557 \\
\hline Italy & $-0.4111^{* *}$ & $-0.4724^{* *}$ & $-6.20 \mathrm{E}-04$ & 0.0228 \\
\hline Luxembourg & $-0.4287^{* *}$ & $-0.408^{* *}$ & $-0.5228^{* *}$ & $-0.781^{* *}$ \\
\hline Netherlands & $-0.279^{* *}$ & $-0.271^{* *}$ & 0.0608 & 0.0926 \\
\hline Austria & -0.0196 & & -0.0163 & 0.2407 \\
\hline Portugal & $-0.7042^{* * *}$ & $-0.6596^{* *}$ & 0.0079 & 0.0532 \\
\hline Finland & 0.0265 & & 0.0106 & -0.093 \\
\hline Sweden & 0.0347 & & 0.1129 & $-0.3735^{* *}$ \\
\hline UK & $-0.2943^{* *}$ & $-0.288^{* *}$ & -0.0779 & -0.0565 \\
\hline Cyprus & $-0.8292^{* *}$ & $-0.7599^{* *}$ & $-0.5708^{* *}$ & $-0.6198^{* *}$ \\
\hline Czech Republic & $-0.4663^{\text {** }}$ & $-0.5104^{* *}$ & 0.1184 & $0.2257^{*}$ \\
\hline Estonia & $-0.2808^{* * *}$ & -0.2248 & -0.104 & -0.0689 \\
\hline Hungary & $-0.394^{* *}$ & $-0.4527^{* *}$ & $-0.5316^{* *}$ & $-0.5758^{* *}$ \\
\hline Latvia & $-0.3761^{\text {*** }}$ & $-0.4139^{* *}$ & -0.1196 & -0.1306 \\
\hline Lithuania & $-0.2957^{* *}$ & -0.2176 & $-0.5572^{* *}$ & $-0.4552^{* *}$ \\
\hline Malta & $-0.4932^{* *}$ & $-0.4885^{* *}$ & -0.0303 & 0.0514 \\
\hline Poland & $-0.2248^{* *}$ & $-0.2533^{* *}$ & -0.0801 & -0.062 \\
\hline Slovakia & $-0.4652^{* * *}$ & $-0.5159^{* *}$ & $0.2574^{*}$ & $0.2354^{*}$ \\
\hline Slovenia & $-0.3003^{* *}$ & $-0.3379^{* *}$ & $-0.3541^{* *}$ & $-0.271^{*}$ \\
\hline Bulgaria & $-0.9756^{* *}$ & $-1.004^{* *}$ & $-0.2139^{*}$ & -0.1921 \\
\hline Romania & $-0.5116^{* *}$ & $-0.4464^{* *}$ & $-0.8958^{* *}$ & $-0.8116^{* *}$ \\
\hline Norway & 0.067 & & 0.0309 & $-0.2293^{*}$ \\
\hline Turkey & $0.323^{* *}$ & & $0.296^{* *}$ & -0.021 \\
\hline Macedonia & $-0.593^{* *}$ & $-0.7726^{* *}$ & $-0.3681^{* *}$ & -0.3057 \\
\hline Croatia & $-0.8159^{* *}$ & $-0.7595^{* *}$ & $0.2542^{*}$ & $0.3363^{* * *}$ \\
\hline Switzerland & $-0.2195^{*}$ & $-0.2158^{* *}$ & $0.3474^{* *}$ & $0.3037^{* *}$ \\
\hline
\end{tabular}

Source: Authors`calculations from Eurobarometer.

Notes: The first two columns estimated by ordered probit. Dependent variable takes a value of 1 if the companies turnover in 2001 decreased by over $25 \%, 2$ if it fell by between $5 \%-25 \%, 3$ if it remained approximately the same, 4 if it grew by $5 \%-25 \%$ and 5 if it grew by more than $25 \%$. The third and fourth columns were estimated by binomial probit. The dependent variable related to whether the company had introduced any innovations since January 2009 , and if so was coded 1 . **** denotes significance at the $1 \% / 5 \%$ levels of significance.

The final set of regressions is shown in Tables 4 and $4 \mathrm{a}$. The first three relate to what firms use public sector services for. We are interested in the different characteristics of firms that use different services. This knowledge is necessary if the public sector is to target and deliver its services efficiently. We add a new variable to the regressions, namely the proportion of the workforce, which went to 
European Financial and Accounting Journal, 2015, vol. 10, no. 1, pp. 19-31.

university. We did not use this in, e.g. the innovation equations due to concerns over endogeneity, i.e. firms, which innovate are more likely to need highly qualified workers. Interestingly those with a high quality workforce tend to make more use of training services, as do larger firms. In terms of sector, retail makes least use of training, followed by the service sector. This may well reflect the skill needs of those sectors, but equally should give training agencies pause for thought on whether they could tailor their services better to the needs of the retail and service sectors.

Tab 4: Firms perceptions and usage of different public services

\begin{tabular}{lcccc}
\hline & $\begin{array}{c}\text { Training \& } \\
\text { safety }\end{array}$ & Use Public services for: & $\begin{array}{c}\text { Views on: } \\
\text { Conformity } \\
\text { certification }\end{array}$ & PS supports \\
\hline Proportion of & $0.0293^{* *}$ & -0.0145 & $0.1401^{* *}$ & $0.0288^{*}$ \\
workforce went & $(2.19)$ & $(1.11)$ & $(8.37)$ & $(2.39)$ \\
to university & -0.0445 & 0.0112 & 0.0023 & 0.0235 \\
Year started & $(1.28)^{* *}$ & $(0.34)^{* *}$ & $(0.05)^{* *}$ & $(0.76)^{* *}$ \\
& $0.3888^{* *}$ & $0.3581^{* *}$ & $0.3495^{* *}$ & $0.0697^{*}$ \\
Size & $(24.96)$ & $(23.43)$ & $(18.35)^{* *}$ & $(4.83)$ \\
Log Domestic & 0.0114 & -0.035 & $-0.0875^{* *}$ & -0.0142 \\
sales & $(0.55)$ & $(1.75)$ & $(3.70)^{* *}$ & $(0.73)^{* *}$ \\
Manufacturing & $-0.099^{*}$ & $-0.1858^{* *}$ & $0.3243^{* *}$ & $-0.1542^{* *}$ \\
& $(2.50)$ & $(4.85)$ & $(6.58)^{* *}$ & $(4.17)^{* *}$ \\
Retail & $-0.1528^{* *}$ & $-0.2703^{* *}$ & $0.1064^{*}$ & $-0.0956^{* *}$ \\
Services & $(4.16)$ & $(7.63)$ & $(2.22)^{* * *}$ & $(2.79)$ \\
& $-0.1127^{* *}$ & $-0.21^{* *}$ & $-0.3251^{* *}$ & -0.0391 \\
Source: Author & $(2.78)$ & $(5.31)$ & $(5.58)$ & $(1.03)$ \\
\hline
\end{tabular}

Source: Authors`calculations from Eurobarometer.

Notes: All the regressions were estimated by ordered probit. The first three columns relate to whether the firm had since January 2000 used public services for (i) training programs, (ii) health and safety issues and (iii) conformity certification for new products. All were coded 1 if the response was 'no', 2 if they had used them less than 5 times and 3 if they had used them 5 times or more. The dependent variable in the final column related to whether the public education and training system had equipped their staff with the knowledge and skills to innovate. It was coded 1 if they strongly disagreed that it had to 4 if they strongly agreed that it had. $* * / *$ denotes significance at the $1 \% / 5 \%$ levels of significance. PS denotes public sector.

Once more there are significant differences among countries and, other things being equal; there is a tendency for the richer countries to use them more. Slovakia once more tends to make less use of such services than others, as do Poland and Hungary, but not the Czech Republic. The third column relates to product certification and is linked to innovation. Larger firms, and those with a skilled workforce, tend to use such services more than other firms, as do those with an export focus. Indeed such certification may well be a prerequisite to gaining access to export markets, which is again something public sector providers need to be 
Orviska, M. - Nemec, J.: Public Sector Innovation Support by European States: Its Characteristics and Impact on Firm.

aware off. Interestingly, this is a service the countries of Central and Eastern Europe, including Slovakia, tend to make more use of than others, possibly due to a greater need to signal product quality in international markets. The final regression relates to training once more and the extent to which the public sector has delivered the skills firms need. Manufacturing firms and smaller firms tend to the view that this is not happening.

\section{Tab 4a: Firms perceptions and usage of different public services}

\begin{tabular}{|c|c|c|c|c|}
\hline & \multicolumn{3}{|c|}{ Use Public services for: } & \multirow{2}{*}{$\begin{array}{c}\text { Views on: } \\
\text { PS supports }\end{array}$} \\
\hline & $\begin{array}{c}\text { Training \& } \\
\text { safety }\end{array}$ & Health & $\begin{array}{c}\text { Conformity } \\
\text { certification }\end{array}$ & \\
\hline Belgium & $0.319^{* *}$ & 0.0757 & 0.0514 & 0.1706 \\
\hline Denmark & -0.0049 & -0.1375 & $-0.8588^{* *}$ & $0.2863^{* *}$ \\
\hline Greece & -0.1244 & $-0.2752^{* *}$ & 0.0471 & $-0.4868^{* *}$ \\
\hline Spain & $0.9216^{* *}$ & $0.4358^{* *}$ & 0.136 & 0.0705 \\
\hline France & $0.6308^{* *}$ & -0.0557 & 0.1029 & 0.0505 \\
\hline Ireland & 0.1305 & -0.1416 & -0.0033 & $0.1781^{*}$ \\
\hline Italy & $0.3544^{* *}$ & $0.3699^{* *}$ & 0.1627 & $-0.2587^{* *}$ \\
\hline Luxembourg & 0.2598 & 0.0626 & 0.2338 & $0.3056^{*}$ \\
\hline Netherlands & $0.5321^{* *}$ & $0.21^{* *}$ & 0.1113 & -0.0011 \\
\hline Austria & $0.5542^{* *}$ & 0.1633 & 0.1669 & $0.2193^{* *}$ \\
\hline Portugal & $0.2401^{*}$ & $0.2842^{* *}$ & 0.0576 & $0.3109^{* *}$ \\
\hline Finland & $0.2056^{*}$ & $0.3662^{* *}$ & 0.1735 & $0.3891^{* *}$ \\
\hline Sweden & 0.1353 & 0.085 & -0.2014 & -0.0826 \\
\hline UK & $0.2181^{* *}$ & -0.0747 & 0.0525 & 0.0669 \\
\hline Cyprus & $0.424^{* *}$ & 0.1584 & 0.2696 & $0.2919^{*}$ \\
\hline Czech Republic & $0.4839^{* *}$ & $0.4037^{* *}$ & $0.3752^{* *}$ & -0.012 \\
\hline Estonia & $0.4357^{* *}$ & $0.5355^{* *}$ & 0.014 & 0.2061 \\
\hline Hungary & 0.064 & $0.1924^{*}$ & 0.1221 & $0.315^{* *}$ \\
\hline Latvia & $0.0461^{* *}$ & 0.1946 & 0.2044 & 0.0378 \\
\hline Lithuania & $0.2519^{*}$ & $0.4229^{* *}$ & 0.2002 & 0.09 \\
\hline Malta & 0.2291 & -0.1227 & -0.3404 & $0.4363^{* *}$ \\
\hline Poland & 0.0957 & $0.3193^{* *}$ & -0.0828 & 0.0278 \\
\hline Slovakia & 0.0607 & $0.3226^{* *}$ & $0.2556^{*}$ & -0.0862 \\
\hline Slovenia & $0.3183^{* *}$ & $0.4916^{* *}$ & $0.6233^{* *}$ & -0.1483 \\
\hline Bulgaria & -0.0899 & $0.1929^{*}$ & 0.1593 & $-0.2379^{* *}$ \\
\hline Romania & 0.0768 & $-0.184^{*}$ & $0.4076^{* * *}$ & $0.5103^{* * *}$ \\
\hline Norway & $-0.5373^{* * *}$ & -0.1266 & $-0.373^{*}$ & $-0.2691^{*}$ \\
\hline Turkey & $-0.2528^{* *}$ & 0.1193 & $0.5353^{* *}$ & $0.4515^{\text {** }}$ \\
\hline Macedonia & 0.1349 & $0.3488^{* *}$ & $0.2867^{*}$ & $0.5172^{* *}$ \\
\hline Croatia & -0.1008 & $0.5848^{* *}$ & $0.5164^{* * *}$ & 0.0655 \\
\hline Switzerland & 0.1022 & -0.0132 & $0.5337^{* *}$ & $0.4802^{* *}$ \\
\hline
\end{tabular}

Source: Authors`calculations from Eurobarometer.

Notes: All the regressions were estimated by ordered probit. The first three columns relate to whether the firm had since January 2000 used public services for (i) training programs, (ii) health and safety issues and (iii) conformity certification for new products. All were coded 1 if the response was 'no', 2 if they had used them less than 5 times and 3 if they had used them 5 times or more. The dependent variable in the final column related to 
European Financial and Accounting Journal, 2015, vol. 10, no. 1, pp. 19-31.

whether the public education and training system had equipped their staff with the knowledge and skills to innovate. It was coded 1 if they strongly disagreed that it had to 4 if they strongly agreed that it had. **/* denotes significance at the $1 \% / 5 \%$ levels of significance. PS denotes public sector.

\section{Conclusion}

We have established that firms benefit from public sector innovation. The factors, which impact on growth, include improvements due to Internet form filling and the reduction in the government's response time with respect to government services. The factors that impact on firm innovation, which may be tomorrow's growth, include the access to information on government services and also factors, which reduce costs. Critical in this is the role of the Internet in facilitating improvements in government services. This indicates that the need for governments is to be at the forefront in introducing changes linked to the Internet, which benefit firms. Of course, in reality it is only firms that can innovate in the private sector, but governments still can make things easier - or harder - for them to do so.

The first set of results relating to where firms thought public sector innovation was greatest do provide information on relative degrees of public sector innovation, but the results are consistent with the conclusion that firms answer this based on their own experiences and that firms focused on the domestic market tend to know most about local and regional governance and larger firms know more about national, rather than local government. This thus provides a lesson against the uncritical interpretation of data to judge, in this case, different degrees of innovation. The final set of results, also provide information the characteristics of firms making use of public services and their satisfaction with those services. One interpretation of these results is that smaller firms with a relatively uneducated workforce are less satisfied with, and not making as much use of, public services as other firms. This raises the question as to whether the public sector could do more to reach these firms?

Throughout the analysis there have been systematic differences among countries. Often these take the form of certain countries, often those at the heart of the financial crisis, but also many in Central and Eastern Europe, lagging behind other countries in the extent to which they grow, innovate and make use of public services. In particular differences in, e.g. the final column of Table 4 relating to whether the public sector supports training are likely to capture actual differences in such provision among countries. In this respect Greece, Italy, Bulgaria and also Norway must do better. Norway of course has huge resources from oil and their sovereign wealth fund. But Greece and Italy in particular are in a parlous position and if these countries are to recover they must make the best use of the resources they have. 
Orviska, M. - Nemec, J.: Public Sector Innovation Support by European States: Its Characteristics and Impact on Firm.

\section{References}

Albury, D., 2005. Fostering innovation in public services. Public Money and Management 25, 51-56.

Bason, C., 2010. Leading public sector innovation: Co-creating for a better society. Oxford, Policy Press.

Bloch, C., Bugge, M. M., 2013. Structural Change and Economic Dynamics 27, 133-145.

Hartley, J., 2005. Innovation in governance and public services: Past and present. Public money and management 25, 27-34.

Heeks, R. (Ed.), 1999. Reinventing government in the information age: International practice in IT-enabled public sector reform. London, Routledge.

Kattel, R., Cepilovs, A., Drechsler, W., Kalvet, T., Lember, V., Tõnurist, P., 2013. Can we measure public sector innovation? A literature review, LIPSE Project paper,

http://www.lipse.org/userfiles/uploads/kattel\%20et\%20al\%20egpa\%20version.pdf

Moore, M., Hartley, J., 2008. Innovations in governance, Public Management Review 10, 3-20.

North, D., Smallbone, D., Vickers, I., 2001. Public sector support for innovating SMEs. Small Business Economics 16, 303-317.

Pollitt, C., 2011. Innovation in the public sector: an innovatory overview. In Bekkers, V., Edelenbos, J., Steijn, B., eds. Innovation in the public sector: linking capacity and leadership, Basingstoke, Palgrave/Macmillan, 35-43.

Schumpeter, J. A., 1912. Theorie der wirtschaftlichen Entwicklung, Berlin, Duncker\&Humblot.

Schumpeter, J. A., 1939. Business Cycles. A Theoretical, Historical, and Statistical Analysis of the Capitalist Process, 1. New York: McGraw-Hill.

Verhoest, K., Verschuere, B., Bouckaert, G., Peters, G. B., 2006. Innovative Public Sector Organizations. In Campell, C. Comparative Trends in Public Management. Smart Practices Toward Blending Policy and Administration. Ottawa: Canada School of Public Service, 106-118.

Wilson, J. Q., 1989. Bureaucracy: what government agencies do and why they do it. New York: Basic Books.

Windrum, P., Koch, P. M., 2008. Innovation in public sector services: entrepreneurship, creativity and management. London, Edward Elgar Publishing. 
European Financial and Accounting Journal, 2015, vol. 10, no. 1, pp. 19-31.

\section{Appendix: Data Definitions for Independent Variables}

Public Sector services improved overall relates to whether public services for business had improved over the past 3 years. Responses 1 for no, deteriorated, 2 for stayed the same and 3 improved.

Internet government form filling relates to whether the option to complete government forms over the Internet had changed since 2009.

Response time for government services relates to the response time for government services.

Access to information on government services relates to ability to access this information

Reduction in financial costs relates to a reduction in the financial costs to the company in connection with using public sector services.

Responses for the previous four questions range from significant deterioration, coded 1, to significant improvement, coded 5.

Year started coded 1 if the firm was started before 1 January 2006, 2 if started between 1 January 2006 and 1 January 2011, and 3 if started after January 1 2011.

Size coded 1 if 1-9 employees, 2 if 10-49 employees, 3 if 50-249 employees and 4 if 250 employees or more.

Domestic sales The proportion of 2011 turnover, which was sold in the firm's own country.

Proportion of workforce went to university The percentage of employees who had a university degree in 2011. 
